\title{
Heat and mass transfer coefficients and modeling of infrared drying of banana slices
}

\author{
Fernanda Machado Baptestini', Paulo Cesar Corrêa ${ }^{2}$, Gabriel Henrique Horta de Oliveira ${ }^{3 *}$ \\ Fernando Mendes Botelho ${ }^{4}$, Ana Paula Lelis Rodrigues de Oliveira ${ }^{3}$
}

$10.1590 / 0034-737 X 201764050002$

\begin{abstract}
Banana is one of the most consumed fruits in the world, having a large part of its production performed in tropical countries. This product possesses a wide range of vitamins and minerals, being an important component of the alimentation worldwide. However, the shelf life of bananas is short, thus requiring procedures to prevent the quality loss and increase the shelf life. One of these procedures widely used is drying. This work aimed to study the infrared drying process of banana slices (cv. Prata) and determine the heat and mass transfer coefficients of this process. In addition, effective diffusion coefficient and relationship between ripening stages of banana and drying were obtained. Banana slices at four different ripening stages were dried using a dryer with infrared heating source with four different temperatures $\left(65,75,85\right.$, and $\left.95^{\circ} \mathrm{C}\right)$. Midilli model was the one that best represented infrared drying of banana slices. Heat and mass transfer coefficients varied, respectively, between 46.84 and $70.54 \mathrm{~W} \mathrm{~m}^{-2} \mathrm{~K}^{-1}$ and 0.040 to $0.0632 \mathrm{~m} \mathrm{~s}^{-1}$ for temperature range, at the different ripening stages. Effective diffusion coefficient ranged from 1.96 to $3.59 \times 10^{-15} \mathrm{~m}^{2} \mathrm{~s}^{-}$ ${ }^{1}$. Activation energy encountered were $16.392,29.531,23.194$, and $25.206 \mathrm{~kJ} \mathrm{~mol}^{-1}$ for $2^{\text {nd }}, 3^{\text {rd }}, 5^{\text {th }}$, and $7^{\text {th }}$ ripening stages, respectively. Ripening stages did not affect the infrared drying of bananas.
\end{abstract}

Key words: ripening; effective diffusion coefficient; mathematical modeling; Musa spp.

\section{RESUMO}

\section{Coeficientes de transferência de calor e massa e modelagem da secagem por infravermelho de fatias de banana}

Banana é uma das frutas mais consumidas no mundo, sendo grande parte de sua produção realizada em países tropicais. Este produto possui uma grande variedade de vitaminas e minerais, sendo um importante componente da alimentação no mundo. Entretanto, a vida de prateleira da banana é curta, requerendo, portanto, procedimentos de modo a prevenir a perda de qualidade e aumentar sua vida de prateleira. Um desses procedimentos é a secagem. Este trabalho objetivou estudar o processo de secagem de fatias de banana ( $\mathrm{Cv}$. Prata) por infravermelho e determinar os coeficientes de transferência de calor e massa desse processo. Em adição, foram obtidos o coeficiente de difusão efetivo e a relação entre os estádios de maturação de bananas e a secagem. Fatias de banana em quatro diferentes estádios de maturação foram secadas usando um secador com fonte de calor por infravermelho em quatro temperaturas distintas $\left(65,75,85\right.$ e $\left.95^{\circ} \mathrm{C}\right)$. O modelo de Midilli foi o que melhor representou a secagem por infravermelho das fatias de banana. Os coeficientes de transferência de calor e massa variaram, respectivamente, entre $46,84 \mathrm{e} 70,54 \mathrm{~W} \mathrm{~m}^{-2} \mathrm{~K}^{-1}$ e 0,040 a $0,0632 \mathrm{~m} \mathrm{~s}^{-1}$ para a faixa de temperatura, em diferentes estádios de maturação. O coeficiente de difusão efetivo

\footnotetext{
Submitted on June 29th, 2015 and accepted on July $12^{\text {th }}, 2017$.

${ }^{1}$ Universidade Federal do Espírito Santo, Departamento de Engenharia Rural, Alegre, Espírito Santo, Brazil. fbaptestini@yahoo.com.br

${ }^{2}$ Universidade Federal de Viçosa, Departamento de Engenharia Agrícola e Ambiental, Viçosa, Minas Gerais, Brazil. copace@ufv.br

${ }^{3}$ Instituto Federal do Sudeste de Minas Gerais, Campus Manhuaçu, Manhuaçu, Minas Gerais, Brazil. gabriel.oliveira@ifsudestemg.edu.br; ana.lelis@ifsudestemg.edu.br

${ }^{4}$ Universidade Federal de Mato Grosso, Campus Sinop, Departamento de Engenharia Agrícola, Sinop, Mato Grosso, Brazil. fernando_eaa@yahoo.com.br

*Corresponding author: gabriel.oliveira@ifsudestemg.edu.br
} 
variou entre 1,96 a $3,59 \times 10^{-15} \mathrm{~m}^{2} \mathrm{~s}^{-1}$. As energias de ativação encontradas foram de 16,$392 ; 29,531 ; 23,194 \mathrm{e} 25,206 \mathrm{~kJ} \mathrm{~mol}^{-}$ ${ }^{1}$ para o $2^{\circ}, 3^{\circ}, 5^{\circ}$ e $7^{\circ}$ estádio de maturação, respectivamente. Os estágios de maturação não afetaram a secagem por infravermelho de bananas.

Palavras-chave: maturação; coeficiente de difusão efetivo; modelagem matemática; Musa spp.

\section{INTRODUCTION}

Banana is one of the most important fruits in the world due to its production and commercialization. Brazil is the fourth biggest producer (6.95 millions of tons), behind India, China, and Philippines (FAO, 2014). For these countries and others, in addition being a complementary food for population, banana production and commercialization are relevant due to its social and economic value. This cultivation is a revenue source for many agricultural families, generating jobs and contributing for the social and economic development of the producing regions. Furthermore, it is responsible for a significant share of agricultural exportation.

Although banana is one of the main products of the Brazilian exportation, its major destination is not to developed countries (USA, Europe). This fact is due to difficulties regarding the demand of high-quality products, which is related to the shelf life, which for bananas, is short. A method to help producers to attend this specific quality required by developed countries and, consequently, achieve a larger amount of market share is the drying process (Borges et al., 2010; Leite et al., 2015). This procedure also prevents production losses related to storage and inappropriate transport.

Drying is a process that removes moisture from the product by means of heat and mass transfer, decreasing biological activity and unwanted chemical and physical characteristics during shelf life. Drying provides an increase of shelf life and results in a lower mass transportation and lower area for the product storage (Sharma et al., 2004). One drying method is by infrared heating source. An advantage of this type of drying is that the infrared radiation used reaches the exposed material, penetrating it and later converting it into heat (Ginzburg, 1969). Thus, this drying method provides elevated heat coefficient values, shorter processing time, and lower energy cost (Nowak \& Lewicki, 2004).

Moisture can move within the product by different mechanisms. In hygroscopic capillary-porous products, such as most agricultural products, the possible mechanisms of moisture movement are liquid, capillary, surface, vapor, and thermal diffusion and hydrodynamic flow (Brooker et al., 1992). Acknowledging effective diffusion coefficient is important to model processes in which mass transfer occurs, such as dehydration, adsorption, and desorption during storage (Pathare \& Sharma, 2006). Different researchers analyzing different products have studied the effective diffusion coefficient (Campos et al., 2009; Corrêa et al., 2010; Corrêa et al., 2012). This parameter illustrates the moisture movement, intrinsic to the product, towards the outside of the product due to drying process.

Heat and mass transfer is intrinsically involved in reducing grain moisture (Hall, 1980) by drying and is one of the main energy-consuming processes encountered in chemical engineering. Simulating the behavior of each product during dehydration is an important parameter to develop and maximize grain drying equipment (Corrêa $e t$ al., 2010; Corrêa et al., 2012), as well as select mathematical models that will represent moisture loss during drying (Honarvar \& Mowla, 2012). Moreover, transport phenomena of food and other important biological materials is a significant link between the processing of these materials and product quality and safety (WeltiChanes et al., 2005).

Thus, the aim of this work was to study the infrared drying process, calculating heat and mass transfer coefficients and effective diffusion coefficient for different ripening stages of banana.

\section{MATERIAL AND METHODS}

Bananas (cv. Prata), purchased from local market of Viçosa-MG, Brazil, were used. Bananas were visually sorted using the classification scale proposed by PBMH \& PIF (2006), in which fruits are separated into seven ripening stages, from totally green to yellow with black spots. In the present work, bananas from four ripening stages were used: light green $\left(2^{\text {nd }}\right)$, half green/half yellow $\left(3^{\text {rd }}\right)$, yellow with green tips $\left(5^{\text {th }}\right)$, yellow with black spots $\left(7^{\text {th }}\right)(\mathrm{PBMH}$ $\&$ PIF, 2006). Moisture content of ripening stages $2^{\text {nd }}, 3^{\text {rd }}$, $5^{\text {th }}$ and $7^{\text {th }}$ were $7.067,7.562,7.562$ and 7.634 , accomplished according to Brasil (2009). 
Bananas were sliced in a transversal way, with approximately $3.0 \mathrm{~mm}$ of thickness and $20 \mathrm{~mm}$ of diameter, from its central part. Banana slices were blanched in boiling water for 2 min to avoid the action of peroxidase enzyme, which promotes darkening of fruits during drying. Afterwards, they were cooled in ambient temperature. In this study, a dryer with an infrared radiation source (model IV 2500, Gehaka, São Paulo, Brazil) was used for dehydration. This equipment contains a scale with $0.001-$ $\mathrm{g}$ precision and an automatic data acquisition system. The radiation source was located at a fixed distance of $15 \mathrm{~mm}$ from the product with an infrared power of $300 \mathrm{~W}$ (Gehaka, 2011). Dehydration was carried out at $65,75,85$, and $95^{\circ} \mathrm{C}$. Dryer provided readings from mass variation at intervals of 1 min. Equilibrium moisture content was achieved when variation of three consecutive mass readings were lower than $0.01 \mathrm{~g}$ from each other.

\section{Mathematical modeling of infrared drying}

Moisture ratio of banana slices during drying was obtained by Equation 1:

$M R=\frac{U_{t}-U_{e}}{U_{i}-U_{e}}$

in which $M R$ is the moisture ratio of the product, dimensionless; $U_{t}$ is the moisture content of the product at a certain drying time, decimal d.b.; $U_{i}$ is the initial moisture content of the product, decimal d.b.; and $U_{e}$ is the equilibrium moisture content of the product, decimal d.b.

Mathematical models frequently applied to represent drying of agricultural products were fitted to the experimental data (time and temperature) of banana drying (Table 1).

To analyze the fitting degree of each model, the magnitudes of the adjusted determination coefficient $\left(\mathrm{R}^{2}\right)$ (explained variance), mean relative error (MRE), the standard deviation of the estimate (SDE), and the analysis of the residual plots generated by the models were used (Corrêa et al., 2012). The residuals (the difference between the observed values and the estimated values by the models) were plotted through the models as a function of the estimated values. A model was considered suitable if the residual values were next to the horizontal line around zero, indicating no tendency in the results. If the residual presented a distribution with tendency, the model was considered inadequate to represent the studied phenomenon.

\section{Heat and mass transfer coefficients}

The theories that govern the constant rate period of dehydration of agricultural products, according to Brooker et al. (1992), can be approximated to the heat and mass transfer balance studies for wet bulb temperature. By means of heat and mass transfer coefficients, the Lewis number was determined (Equation 9). This is used to characterize the fluid flow when a process of heat and mass transfer occurs throughout convection (Incropera \& Dewitt, 2003):

$$
\frac{h_{c}}{h_{m}}=\rho C_{p} L_{e}^{1-n}=\rho C_{p}\left(\frac{S c}{P r}\right)^{1-n},
$$

in which $\tilde{n}$ is the specific mass of the air, $\mathrm{kg} \mathrm{m}^{-3} ; C_{p}$ is the specific heat of the air, $\mathrm{J} \mathrm{kg}^{-1} \mathrm{~K}^{-1} ; L_{e}$ is the Lewis number, dimensionless; $S c$ is the Schmidt number, dimensionless; and $\operatorname{Pr}$ is the Prandtl number, dimensionless.

Equation 9 can be used for both turbulent and laminar flow, in which at most applications, it is reasonable to admit an $n$ value of $1 / 3$. To calculate Lewis number, values of Schmidt and Prandtl number were encountered at Brooker et al. (1992). Specific mass of the air for each drying temperature were corrected in function of the altitude and acquired using software GRAPSI ${ }^{\circledR}$.

\section{Effective diffusion coefficient}

The effective diffusion coefficient $\left(\boldsymbol{D}_{e f}\right)$ was obtained by adjusting the liquid diffusion mathematical model (Corrêa et al., 2012) to the experimental data of the descending period of dehydration. This equation is the analytical solution for Fick's second law, which takes into account the flat geometric shape and the contour condition of the known moisture on the surface of the product and neglects the volumetric shrinkage of the product.

Table 1: Mathematical models used to represent the drying phenomenon of banana slices

\begin{tabular}{llr}
\hline Model name & \multicolumn{1}{c}{ Model } & Equation \\
\hline Diffusion approximation (Yaldiz \& Ertekin, 2001) & $M R=a \exp (-k t)+(1-a) \exp (-k b t)$ & $(2)$ \\
Two-Terms (Henderson, 1974) & $M R=a \exp (-k t)+b \exp (-g t)$ & $(3)$ \\
Henderson \& Pabis(Henderson \& Pabis, 1961) & $M R=a \exp (-k t)$ & $(4)$ \\
Midilli (Midilli et al., 2002) & $M R=a \exp \left(-k t^{n}\right)+b t$ & $(5)$ \\
Logarithmic (Yagcioglu et al., 1999) & $M R=a \exp (-k t)+b$ & $(7)$ \\
Verma (Verma et al., 1985) & $M R=a \exp (-k t)+(1-a) \exp (-g t)$ & $(8)$ \\
Page (Diamente \& Munro, 1993) & $M R=\exp \left(-k t^{n}\right)$ &
\end{tabular}

$a, b, g$, and $n$ are model parameters, dimensionless; $k$ is the drying rate, $\mathrm{s}^{-1}$; and $t$ is drying time, $\mathrm{s}$. 
$M R=\frac{U_{t}-U_{e}}{U_{i}-U_{e}}=\frac{8}{\pi^{2}} \sum_{n=0}^{\infty} \frac{1}{(2 n+1)^{2}} \exp \left[-\frac{(2 n+1)^{2} \pi^{2} D_{e f} t}{4 L^{2}}\right]$,

in which $L$ is the thickness of the slab (m); $D_{e f}$ is the effective diffusion coefficient $\left(\mathrm{m}^{2} \mathrm{~s}^{-1}\right) ; n$ is the number of equation parameters; and $t$ is drying time, $\mathrm{s}$.

Analytical solution of Equation 10 is presented in an infinite series. Thus, the number of finite terms $(n)$ at truncation determinates the precision of results. For long dehydration periods ( $\mathrm{MR}<0.6$ ), the diffusion equation can be simplified by a one-term series (Senadeera et al., 2003).

\section{Activation energy}

To acquire the activation energy, Arrhenius equation was used. This method is widely used at specialized literature (Doymaz et al., 2006; Gely \& Santalla, 2007).

\section{Statistical analysis}

The experiment was performed in a factorial scheme of $4 \times 4$ (four temperatures and four ripening stages), in a completely randomized design, with five replicates.

Experimental data were subjected to preliminary tests to verify the normality and homogeneity of the variance of the data, using the Lilliefors and Bartlett tests, respectively. Afterwards, experimental data were subjected to analysis of variance at $5 \%$ level of probability. The $\mathrm{F}$ test was used for the qualitative factor and regression analysis for the quantitative factor.

The models were chosen based on the significance of the regression coefficients, using the $t$ test, at $1 \%$ and $5 \%$ level of probability, and by the determination coefficient $\left(\mathrm{R}^{2}\right)$.

\section{RESULTS AND DISCUSSION}

It is known that during fruit ripening, several important phenomena occur, such as transformation of starch into sugar and deterioration of cell walls with consequent juice loss from the pulp tissues. This last trend may interfere in different physical characteristics and leads to tissues more or less susceptible to heat transfer and permeable to mass transfer. Thus, it interferes in the heat and mass transfer coefficients.

It can be noticed that heat and mass transfer coefficient increased with temperature increase at all ripening stages (Table 2). Its values ranged from 46.85 to $70.53 \mathrm{~W} \mathrm{~m}^{-2} \mathrm{~K}$ and 0.0404 to $0.0632 \mathrm{~m} \mathrm{~s}^{-1}$ for heat and mass transfer coefficients, respectively. Corrêa et al. (2009) dried apple slices by infrared with temperatures between 50 and 100 ${ }^{\circ} \mathrm{C}$, obtaining values of heat transfer coefficient between 45.97 and $89.40 \mathrm{~W} \mathrm{~m}^{-2} \mathrm{~K}^{-1}$ and mass transfer coefficient between 0.0434 and $0.0759 \mathrm{~m} \mathrm{~s}^{-1}$, which are similar to those found in the present work. According to Bird et al. (2004), the typical order of magnitude for heat transfer coefficient for convection is between 3.0 and $20.0 \mathrm{~W} \mathrm{~m}^{-2}{ }^{\circ} \mathrm{C}$, denoting the faster drying process by infrared. The main reason for higher values of heat and mass transfer coefficients in the present work is due to the fact that drying is not solely convective, but a mix of radiation and convection processes (Corrêa et al., 2009). According to Corrêa et al. (2009), coefficients are dependent upon boundary conditions, which are influenced by surface geometry, flow movement, and several thermodynamic properties. Touré \& KibanguNkembo (2004) reported values of mass transfer coefficient ranging from 0.00876 to $0.00943 \mathrm{~m} \mathrm{~s}^{-1}$ for two banana varieties subjected to natural solar drying. These values were lower than the ones found in the present work due to the higher efficiency of infrared drying related to the infrared radiation penetration in the material, being converted to heat and promoting an easier removal of water. It can be observed that both heat and mass transfer coefficients presented linear behavior with temperature, a trend also observed in previous work (Corrêa et al., 2009; Jaturonglumlert \& Kiatsiriroat, 2010).

Values of Lewis number were 1.11, 1.14, 1.16, and 1.17 for all ripening stages and drying temperatures of 65,75 , 85 , and $95^{\circ} \mathrm{C}$, respectively. These were compared to calculated Lewis number by means of relationship between Prandtl and Schmidt number $(0.909,0.915,0.918$, and 0.920 for drying temperatures of $65,75,85$, and $95^{\circ} \mathrm{C}$, respectively). It can be noticed that values found are slightly higher because heat and mass transfer by infrared drying are driven by convection and radiation. According to Hatami \& Ganji (2014), Lewis number is an indicative of the heat and mass transfer processes: if Le $\gg 1$, the process is limited by the mass transfer; if Le $<<1$, the process is limited by the heat transfer; and if $\mathrm{Le}=1$, the process is driven by both processes. From the values encountered (1.11 to 1.17), it can be concluded that infrared drying of banana slices in four ripening stages at four temperatures is driven by the coupled processes (heat and mass transfer).

Table 3 shows the values of MRE, SDE, and $\mathrm{R}^{2}$ for each model considered in the present study, used to represent the infrared drying of banana slices. Determining the coefficient $\left(\mathrm{R}^{2}\right)$ for non-linear models is not a good decision-making tool (Corrêa et al., 2010). It is necessary to analyze different statistical parameters. Thus, for model adequacy in describing a phenomenon, $M R E$ values must be taken into consideration; the lowest values of $M R E$ indicate a higher representation of the model for the phenomenon under study and its values must be under $10 \%$ (Mohapatra \& Rao, 2005). Analyzing SDE also helps to select models. Lower SDE values indicate higher model reliability. Finally, mathematical modeling for drying 
Table 2: Heat $\left(h_{c}\right)$ and mass $\left(h_{m}\right)$ transfer coefficients of banana slices at $2^{\text {nd }}, 3^{\text {rd }}, 5^{\text {th }}$, and $7^{\text {th }}$ ripening stage, dried at temperatures of $65,75,85$, and $95^{\circ} \mathrm{C}$ and their respective regression equations with determination coefficients $\left(\mathrm{R}^{2}\right)$, by means of average results, as a function of temperature $(\mathrm{T})$

\begin{tabular}{|c|c|c|c|c|}
\hline \multirow{2}{*}{ Ripening stage } & \multicolumn{4}{|c|}{ Temperature $\left({ }^{\circ} \mathrm{C}\right)$} \\
\hline & 65 & 75 & 85 & 95 \\
\hline \multicolumn{5}{|c|}{$h_{c}\left(\mathrm{~W} \mathrm{~m}^{-2} \mathrm{~K}^{-1}\right)$} \\
\hline $2^{\text {nd }}$ & 55.50 & 57.46 & 59.56 & 70.53 \\
\hline $3^{\text {rd }}$ & 51.69 & 55.10 & 57.11 & 68.46 \\
\hline $5^{\text {th }}$ & 56.50 & 57.88 & 61.57 & 64.68 \\
\hline $7^{\text {th }}$ & 50.89 & 46.85 & 60.10 & 62.81 \\
\hline Average & 53.64 & 54.32 & 59.58 & 66.62 \\
\hline \multicolumn{4}{|c|}{ Regression equation: $h_{c}=23.1872+0.4419 * * \times T$} & $\mathrm{R}^{2}: 0.9028$ \\
\hline \multicolumn{5}{|c|}{$h_{m}\left(\mathrm{~m} \mathrm{~s}^{-1}\right)$} \\
\hline $2^{\text {nd }}$ & 0.0473 & 0.0496 & 0.0523 & 0.0632 \\
\hline $3^{\text {rd }}$ & 0.0440 & 0.0476 & 0.0501 & 0.0614 \\
\hline $5^{\text {th }}$ & 0.0481 & 0.0500 & 0.0528 & 0.0580 \\
\hline $7^{\text {th }}$ & 0.0433 & 0.0404 & 0.0527 & 0.0563 \\
\hline Average & 0.0457 & 0.0469 & 0.0520 & 0.0597 \\
\hline \multicolumn{4}{|c|}{ Regression equation: $h_{m}=0.01133+0.0005^{* *} \times T$} & $\mathrm{R}^{2}: 0.9118$ \\
\hline
\end{tabular}

\footnotetext{
* Significant at $1 \%$ of probability by the $\mathrm{t}$ test.
}

** Significant at $5 \%$ of probability by the $\mathrm{t}$ test.

Table 3: Values of mean relative error (MRE), standard deviation of the estimate (SDE), and determination coefficient $\left(\mathrm{R}^{2}\right)$ for each mathematical model studied in the temperatures (T) of $65,75,85$, and $95^{\circ} \mathrm{C}$, for banana infrared drying

\begin{tabular}{|c|c|c|c|c|}
\hline $\mathbf{T}\left({ }^{\circ} \mathrm{C}\right)$ & Model name & $\mathbf{R}^{2}(\%)$ & $\operatorname{MRE}(\%)$ & SDE (decimal d.b.) \\
\hline \multirow{7}{*}{65} & Diffusion approximation & 99.98 & 10.98 & 0.0032 \\
\hline & Two-terms & 99.98 & 10.85 & 0.0031 \\
\hline & Henderson and Pabis & 99.66 & 10.68 & 0.0136 \\
\hline & Logarithmic & 99.73 & 23.23 & 0.0122 \\
\hline & Midilli & 99.98 & 3.78 & 0.0031 \\
\hline & Page & 99.95 & 15.94 & 0.0052 \\
\hline & Verma & 99.98 & 10.98 & 0.0032 \\
\hline \multirow{7}{*}{75} & Diffusion approximation & 99.99 & 7.39 & 0.0023 \\
\hline & Two-terms & 99.99 & 7.28 & 0.0022 \\
\hline & Henderson and Pabis & 99.72 & 11.67 & 0.0123 \\
\hline & Logarithmic & 99.79 & 21.42 & 0.0107 \\
\hline & Midilli & 99.98 & 4.04 & 0.0030 \\
\hline & Page & 99.97 & 10.92 & 0.0040 \\
\hline & Verma & 99.99 & 7.39 & 0.0023 \\
\hline \multirow{7}{*}{85} & Diffusion approximation & 99.98 & 7.77 & 0.0032 \\
\hline & Two-terms & 99.98 & 7.73 & 0.0032 \\
\hline & Henderson and Pabis & 99.61 & 15.61 & 0.0147 \\
\hline & Logarithmic & 99.72 & 13.51 & 0.0123 \\
\hline & Midilli & 99.96 & 9.48 & 0.0046 \\
\hline & Page & 99.95 & 9.15 & 0.0049 \\
\hline & Verma & 99.98 & 7.77 & 0.0032 \\
\hline \multirow{7}{*}{95} & Diffusion approximation & 99.98 & 5.15 & 0.0025 \\
\hline & Two-terms & 99.99 & 5.12 & 0.0024 \\
\hline & Henderson and Pabis & 99.62 & 12.44 & 0.0147 \\
\hline & Logarithmic & 99.72 & 14.47 & 0.0127 \\
\hline & Midilli & 99.98 & 5.97 & 0.0036 \\
\hline & Page & 99.96 & 8.04 & 0.0047 \\
\hline & Verma & 99.99 & 5.15 & 0.0025 \\
\hline
\end{tabular}


phenomenon should indicate a single model in different temperatures used. Therefore, by analyzing these three statistical parameters (Table 3), it was concluded that the Midilli model is the best to represent infrared drying of banana slices, especially at the lower drying temperatures. As a result, Figure 1 represents the banana drying curve. This figure shows the drying values observed and estimated by the Midilli model at the $2^{\text {nd }}$ ripening stage dried at $65^{\circ} \mathrm{C}$. By analyzing Figure 1, the good adjustment of the Midilli model to the experimental data can be observed, which satisfactorily represents banana drying kinetics.

Figure 1 shows that some linearity occurs until approximately $20 \mathrm{~min}$ after the moisture ratio is reduced followed by an exponential reduction. The critical moisture content is defined at this point. This parameter divides the drying curve into two parts: constant drying rate (before 20 min of drying) and decreasing falling rate (after 20 min of drying). In the first part, a constant falling rate period occurs, in which the velocities of moisture removal at the periphery and moisture replacement from the center to the periphery are considered equal (Corrêa et al., 2012). In the second part, a decrease in the moisture ratio with lower velocity is observed, in which moisture replacement previously observed cannot supply the removal of moisture by infrared drying at the same velocity. By analyzing the linearity of experimental data, a critical moisture content of $0.71,0.58,0.49$, and 0.43 (d.b.) was found for banana infrared drying respectively for the $2^{\text {nd }}$, $3^{\text {rd }}, 5^{\text {th }}$, and $7^{\text {th }}$ ripening stage. Santos et al. (2011) reported values of 2.81 and $3.10 \%$ (d.b.), respectively, for Fuji and Gala apple varieties. Corrêa et al. (2012) found a critical moisture content of $2.97 \%$ (d.b.) for tomato slices dried by infrared.

Table 4 presents the values of effective diffusion coefficient $\left(D_{e f}\right)$ for banana slices, in different ripening stages, dried by infrared at temperatures of $65,75,85$ and $95{ }^{\circ} \mathrm{C}$. It can be observed that $D_{e f}$ values increased with increasing drying temperature, varying magnitude order of $10^{-15} \mathrm{~m}^{2} \mathrm{~s}^{-1}$. Doymaz (2008), studying convective drying of strawberries, stated that $D_{e f}$ values are generally in the range of $10^{-11}$ to $10^{-9} \mathrm{~m}^{2} \mathrm{~s}^{-1}$. Doymaz (2008) affirmed that the major problem for drying of fruits such as grapes, apricots, plums, and strawberries is the presence of natural wax covering these products, which reduces the diffusion. Furthermore, in the present work, convection is not forced, but merely a natural convective process, leading to lower values of $D_{e f}$

Another reason for the $D_{e f}$ values to be lower than the range previously stated is that the internal temperature of the product being dehydrated, and consequently diffusion, is increased due to an increment of radiation intensity (Afzal \& Abe, 1998). Temperature increase also interferes in other fluid physical properties (air and water), contributing to an increase of $D_{e f}$ According to Corrêa $e t$ al. (2009), two of them are more important to agricultural products: viscosity and molecular vibration of water and air molecules. The first is directly related to water transport in the porous media capillary. The second diminishes air vapor pressure and increases vapor pressure in the product, leading to an increment of water concentration gradient, facilitating water removal. Thus, the lower values of effective diffusion coefficient in the present work was not expected, since this natural covering on banana slices

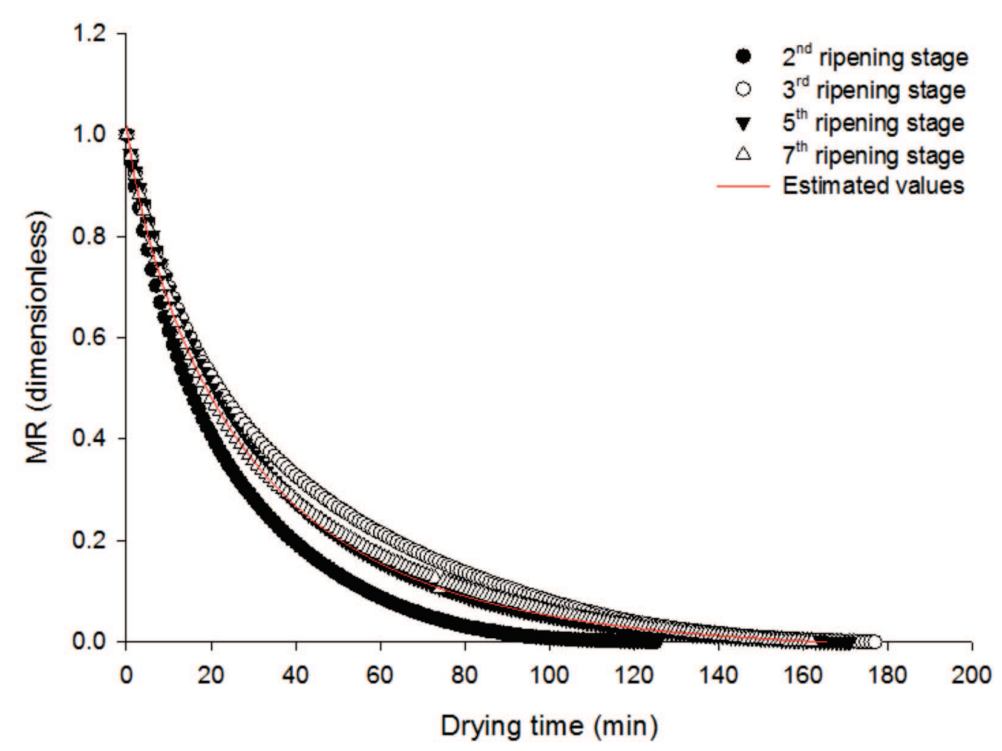

Figure 1: Observed and estimated moisture ratio $(M R)$ values by the Midilli model during drying of banana slices at $65^{\circ} \mathrm{C}$ at different ripening stages.

Rev. Ceres, Viçosa, v. 64, n.5, p. 457-464, set/out, 2017 
Table 4: Effective diffusion coefficients $\left(D_{e f} \mathrm{~m}^{2} \mathrm{~s}^{-1}\right)$ for infrared drying of banana slices at $2^{\text {nd }}, 3^{\text {rd }}, 5^{\text {th }}$ and $7^{\text {th }}$ ripening stages, as a function of drying temperature $(\mathrm{T})$

\begin{tabular}{lcccc}
\hline \multirow{2}{*}{ Ripening stage } & \multicolumn{5}{c}{$\mathbf{T}\left({ }^{\circ} \mathbf{C}\right)$} \\
\cline { 2 - 5 } & $\mathbf{6 5}$ & $\mathbf{7 5}$ & $\mathbf{8 5}$ & $\mathbf{9 5}$ \\
\hline $2^{\text {nd }}$ & $2.45 \times 10^{-15}$ & $2.88 \times 10^{-15}$ & $3.17 \times 10^{-15}$ & $3.94 \times 10^{-15}$ \\
$3^{\text {rd }}$ & $1.62 \times 10^{-15}$ & $2.32 \times 10^{-15}$ & $3.45 \times 10^{-15}$ & $3.44 \times 10^{-15}$ \\
$5^{\text {th }}$ & $1.87 \times 10^{-15}$ & $2.50 \times 10^{-15}$ & $2.93 \times 10^{-15}$ & $3.64 \times 10^{-15}$ \\
$7^{\text {th }}$ & $1.87 \times 10^{-15}$ & $2.56 \times 10^{-15}$ & $2.74 \times 10^{-15}$ & $3.34 \times 10^{-15}$ \\
\hline Average & $1.96 \times 10^{-15}$ & $2.57 \times 10^{-15}$ & $3.07 \times 10^{-15}$ & $3.59 \times 10^{-15}$ \\
\hline Regression equation: $D=-2.0 \times 10^{-15 *}+5.0 \times 10^{-17^{*}} \times T$ \\
\hline
\end{tabular}

Regression equation: $D_{e f}=-2.0 \times 10^{-15^{*}}+5.0 \times 10^{-17^{*}} \times T \quad \mathrm{R}^{2}: 0.9980$

"Significant at $1 \%$ of probability by the $\mathrm{t}$ test.

was not present and radiation was used. However, according to Chen (2006), some agricultural products during drying develops a dried crust, which hinders water removal and thus reduces the effective diffusion coefficient. The same fact occurred in the present work, which was visually confirmed.

Different researches with different products encountered different values of effective diffusion coefficient. Corrêa et al. (2012), working with tomato infrared drying, encountered values of $D_{e f}$ for three ripening stages (green, orange, and red) of 3.33, 2.78, and $3.05 \times 10^{-7} \mathrm{~m}^{2} \mathrm{~s}^{-1}$. Sharma et al. (2004), who dried onion slices by infrared, encountered values between $0.21 \times 10$ ${ }^{10}$ and $1.57 \times 10^{-10} \mathrm{~m}^{2} \mathrm{~s}^{-1}$. Also by infrared drying, Afzal \& Abe (1998) reported values between $5.93 \times 10^{-11}$ and 1.73 $\times 10^{-9} \mathrm{~m}^{2} \mathrm{~s}^{-1}$ for potato slices.

Activation energy of water diffusivity for banana slices during infrared drying for temperature range $(65,75,85$, and $95^{\circ} \mathrm{C}$ ) and for the $2^{\text {nd }}, 3^{\text {rd }}, 5^{\text {th }}$, and $7^{\text {th }}$ ripening stages used were $15.767 \mathrm{~kJ} \mathrm{~mol}^{-1}, 27.557 \mathrm{~kJ} \mathrm{~mol}^{-1}, 22.218 \mathrm{~kJ} \mathrm{~mol}^{-1}$, and $18.649 \mathrm{~kJ} \mathrm{~mol}^{-1}$, respectively. Zogzas et al. (1996) reported that activation energy generally ranges from 12.7 to $110.0 \mathrm{~kJ} \mathrm{~mol}^{-1}$ for food; therefore, consistent values were achieved in this study.

\section{CONCLUSIONS}

According to the results of the present work, the following statements regarding infrared drying process of banana slices can be concluded:

1. Relationship between heat and mass transfer coefficients and ripening stage was not observed.

2. Midilli model was the one that best represented infrared drying process of banana slices.

3. Heat and mass transfer coefficients increased with increasing drying temperature.

4. Later ripening stage increased the Lewis number, indicating that infrared drying process is driven by both heat and mass transfer.
5. Effective diffusion coefficient values are dependent upon infrared drying process temperature, confirmed by Arrhenius equation.

6. Activation energy values did not present a linear behavior with ripening stages.

\section{REFERENCES}

Afzal TM \& Abe T (1998) Diffusion in potato during far infrared radiation drying. Journal of Food Engineering, 37:353-365.

Bird RB, Stewart WE \& Lightfoot EN (2004) Fenômenos de Transporte. $2^{\mathrm{a}}$ ed. Rio de Janeiro, LTC. 838p.

Borges SV, Mancini MC, Corrêa JLG \& Leite J (2010) Secagem de bananas prata e d'água por convecção forçada. Ciência e Tecnologia de Alimentos, 30:605-612.

Brasil (2009) Regras para análise de sementes. Brasília, Ministério da Agricultura e Reforma Agrária, Secretaria Nacional de defesa Agropecuária. 395p.

Brooker DB, Bakker-Arkema FW \& Hall CW (1992) Drying and storage of grains and oilseeds. Westport, The AVI Publishing Company. 450p.

Campos SC, Corrêa PC, Botelho FM, Nogueira BL, Oliveira GHH \& Paixão AA (2009) Avaliação da secagem dos grãos de café de diferentes etapas do processamento via úmida. Revista Brasileira de Armazenamento, Especial Café:88-98.

Chen XD (2006) Lewis number in the context of air-drying of hygroscopic materials. Separation and Purification Technology, 48:121-132.

Corrêa PC, Santos ES, Botelho FM \& Baptestini FM (2009) Determinação dos coeficientes de transferência de calor e de massa da desidratação por infravermelho de fatias de maçã Fuji e Gala. In: Di Leo N, Montico S \& Nardón G (Eds.) Avances en Ingeniería Rural. Rosario, UNR Editora. p.1060-1066.

Corrêa PC, Oliveira GHH, Botelho FM, Goneli ALD \& Carvalho FM (2010) Modelagem matemática e determinação das propriedades termodinâmicas do café (Coffea arabica L.) durante o processo de secagem. Revista Ceres, 57:595-601.

Corrêa PC, Oliveira GHH, Baptestini FM, Diniz MDMS \& Paixão AA (2012) Tomato infrared drying: modeling and some coefficients of the dehydration process. Chilean Journal of Agricultural Research, 72:262-267.

Diamente LM \& Munro PA (1993) Mathematical modelling of the thin layer solar drying of sweet potato slices. Solar Energy, 51:271-276.

Rev. Ceres, Viçosa, v. 64, n.5, p. 457-464, set/out, 2017 
Doymaz I (2008) Convective drying kinetics of strawberry. Chemical Engineering and Processing, 47:914-919.

Doymaz I, Tuðrul N \& Pala M (2006) Drying characteristics of dill and parsley leaves. Journal of Food Engineering, 77:559565 .

FAO - Food and Agriculture Organization (2014) FAOSTAT. Available at: <http://www.fao.org/faostat/en/\#data/QC> Accessed on: June 08 ${ }^{\text {th }}, 2017$.

Gehaka (2011) Manual Medidor de Umidade por Infravermelho IV 2500. Available at: <http://www.gehaka.com.br/sistema/produtos/278/m_iv2500.pdf $>$. Accessed on: May 08 2015.

Gely MC \& Santalla EM (2007) Moisture diffusivity in quinoa (Chenopodium quinoa Willd.) seeds: Effect of air temperature and initial moisture content of seeds. Journal of Food Engineering, 78:1029-1033.

Ginzburg AS (1969) Application of Infrared Radiation in Food Processing. London, The Book Service Publisher. 412p.

Hall CW (1980) Drying and storage of agricultural crops. Westport, AVI Publishing Company. 381p.

Hatami M \& Ganji DD (2014) Investigation of refrigeration efficiency for fully wet circular porous fins with variable section by combined heat and mass transfer analysis. International Journal of Refrigeration, 40:140-151.

Henderson SM (1974) Progress in developing the thin-layer drying equation. Transactions of the ASAE, 17:1167-1168

Henderson SM \& Pabis S (1961) Grain drying theory. I. Temperature effect on drying coeffiient. Journal of Agriculture Engineering Research, 6:169-174.

Honarvar B \& Mowla D (2012) Theoretical and experimenta drying of a cylindrical sample by applying hot air and infrared radiation in an inert medium fluidized bed. Brazilian Journal of Chemical Engineering, 29:231-242.

Incropera FP \& Dewitt DP (2003) Fundamentos de Transferência de Calor e Massa. 5 ${ }^{\text {a }}$ ed. Rio de Janeiro, Editora LTC. 698p.

Jaturonglumlert S \& Kiatsiriroat T (2010) Heat and mass transfer in combined convective and far-infrared drying of fruit leather. Journal of Food Engineering, 100:254-260.

Leite ALMP, Silva FS, Porto AG, Piasson D \& Santos P (2015) Contração volumétrica e cinética de secagem de fatias de banana variedade Terra. Pesquisa Agropecuária Tropical, 45:155162

Midilli A, Kucuk H \& Yapar Z (2002) A new model for single layer drying. Drying Technology, 20:1503-1513.
Mohapatra D \& Rao PS (2005) A thin layer drying model of parboiled wheat. Journal of Food Engineering, 66:513-518.

Nowak D \& Lewicki PP (2004) Infrared drying of apple slices. Innovative Food Science and Emerging Technologies, 5:353360 .

Pathare PB \& Sharma GP (2006) Effective Moisture Diffusivity of Onion Slices undergoing Infrared Convective Drying. Biosystems Engineering, 93:285-291.

PBMH \& PIF - Programa Brasileiro para a Modernização da Horticultura \& Produção Integrada de Frutas (2006) Normas de Classificação de Banana. São Paulo, CEAGESP. (Documentos, 29).

Senadeera W, Bhandari BR, Young G \& Wijesinghe B (2003) Inûuence of shapes of selected vegetable materials on drying kinetics during ûuidized bed drying. Journal of Food Engineering, 58:277-283

Sharma GP, Verma RC \& Pathare PB (2004) Thin-layer infrared radiation drying of onion slices. Journal of Food Engineering, 67:361-366.

Santos ES, Corrêa PC, Baptestini FM, Botelho FM \& Magalhães FEA (2011) Mathematical modeling of dehydration of 'Fuji' and 'Gala' apples slices using infrared. Ciência e Tecnologia de Alimentos, 31:776-781.

Touré S \& Kibangu-Nkembo S (2004) Comparative study of natural solar drying of cassava, banana and mango. Renewable Energy, 29:975-990.

Verma LR, Bucklin RA, Endan JB \& Wratten FT (1985) Effects of drying air parameters on rice dryingmodels. Transaction of ASAE, 28:296-301

Welti-Chanes J, Vergara-Balderas F \& Bermúdez-Aguirre D (2005) Transport phenomena in food engineering: Basic concepts and advances. Journal of Food Engineering, 67:113-128.

Yagcioglu A, Degirmencioglu A \& Cagatay F (1999) Drying characteristic of laurel leaves under different conditions. In: $7^{\text {th }}$ International Congress on Agricultural Mechanization and Energy, Adana. Proceedings, Ege University. p.565-569.

Yaldiz O \& Ertekin C (2001) Thin layer solar drying some different vegetables. Drying Technology, 19:583-597.

Zogzas NP, Maroulis ZB \& Marinoskouris D (1996) Moisture diffusivity data compilation in foodstuffs. Drying Technology, 14:2225-2253. 